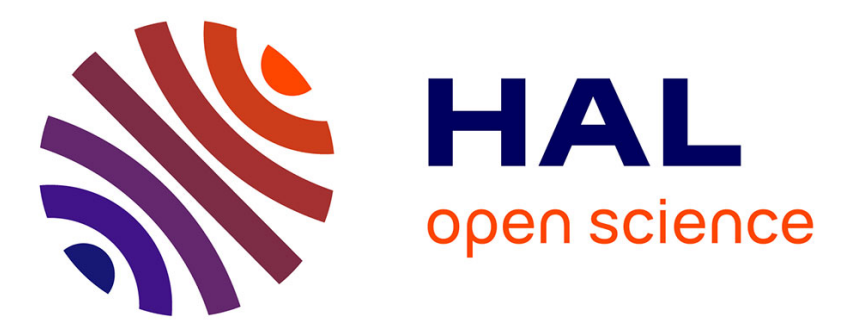

\title{
A Trans-Siberian tidal Gravity Profile (TSP) for the validation of the ocean tides loading corrections
}

\author{
Bernard Ducarme, V.Yu. Timofeev, M. Everaerts, P.Y. Gornov, V.A. \\ Parovishnii, M. van Ruymbeke
}

\section{To cite this version:}

Bernard Ducarme, V.Yu. Timofeev, M. Everaerts, P.Y. Gornov, V.A. Parovishnii, et al.. A TransSiberian tidal Gravity Profile (TSP) for the validation of the ocean tides loading corrections. Journal of Geodynamics, 2008, 45 (2-3), pp.73. 10.1016/j.jog.2007.07.001 . hal-00531878

\section{HAL Id: hal-00531878 https://hal.science/hal-00531878}

Submitted on 4 Nov 2010

HAL is a multi-disciplinary open access archive for the deposit and dissemination of scientific research documents, whether they are published or not. The documents may come from teaching and research institutions in France or abroad, or from public or private research centers.
L'archive ouverte pluridisciplinaire HAL, est destinée au dépôt et à la diffusion de documents scientifiques de niveau recherche, publiés ou non, émanant des établissements d'enseignement et de recherche français ou étrangers, des laboratoires publics ou privés. 


\section{Accepted Manuscript}

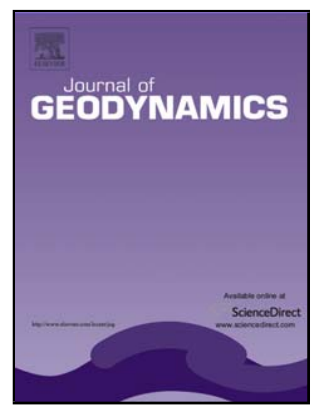

Title: A Trans-Siberian tidal Gravity Profile (TSP) for the validation of the ocean tides loading corrections

Authors: B. Ducarme, V.Yu. Timofeev, M. Everaerts, P.Y.

Gornov, V.A. Parovishnii, M. van Ruymbeke

PII: $\quad$ S0264-3707(07)00054-3

DOI: $\quad$ doi:10.1016/j.jog.2007.07.001

Reference: $\quad$ GEOD 817

To appear in: $\quad$ Journal of Geodynamics

Received date: 24-1-2007

Revised date: 25-5-2007

Accepted date: $\quad$ 2-7-2007

Please cite this article as: Ducarme, B., Timofeev, V.Yu., Everaerts, M., Gornov, P.Y., Parovishnii, V.A., van Ruymbeke, M., A Trans-Siberian tidal Gravity Profile (TSP) for the validation of the ocean tides loading corrections, Journal of Geodynamics (2007), doi:10.1016/j.jog.2007.07.001

This is a PDF file of an unedited manuscript that has been accepted for publication. As a service to our customers we are providing this early version of the manuscript. The manuscript will undergo copyediting, typesetting, and review of the resulting proof before it is published in its final form. Please note that during the production process errors may be discovered which could affect the content, and all legal disclaimers that apply to the journal pertain. 


\section{A Trans-Siberian tidal Gravity Profile (TSP) \\ for the validation of the ocean tides loading corrections}

Ducarme B. ${ }^{(1)}$, Timofeev V.Yu. ${ }^{(2)}$, Everaerts M. ${ }^{(3)}$, Gornov P.Y. ${ }^{(4)}$, Parovishnii V.A. ${ }^{(5)}$, van Ruymbeke M. ${ }^{(3)}$

${ }^{(1)}$ Research Associate NFSR, Royal Observatory of Belgium, av. Circulaire 3, B1180 Brussels

(2) Trofimuk Institute of Petroleum Geology and Geophysics SB RAS, 3 pr. Ak. Koptyuga, 630090 Novosibirsk, Russia

(3) Royal Observatory of Belgium, Av. Circulaire 3, B-1180 Brussels, Belgium

(4) Institute of Tectonic and Geophysics FED RAS, Khabarovsk, Russia.

(5) Institute of Marine Geology and Geophysics FED RAS, Yuzhno-Sakhalinsk, Russia

corresponding author: Bernard Ducarme

Royal Observatory of Belgium, Av. Circulaire 3, B-1180 Brussels, Belgium

ducarme@oma.be 


\section{ABSTRACT}

Tidal gravity observations have been performed across Siberia, along a profile extending from Novosibirsk to the West until Sakhalin Island to the East. All the stations were occupied by the same instrument (LCR402) for periods ranging from one to more than two years. The first goal was to compare the observed tidal parameters of the main tidal waves O1, K1 and M2 with modelled ones computed from 9 different ocean tides models: SCW80, ORI96, CSR3, FES95, FES02, CSR4, GOT00, NAO99 and TPX06. In order to assess the overall accuracy of tidal predictions across Siberia, we selected also the best ocean tides models for Long Period Tides, on the basis of previous comparisons.

The observed amplitude factors and phase differences agree with the modelled ones within the associated RMS errors, generally at the level of $0.3 \%$. On the other hand, the predicted tidal factors, computed from different ocean tides models, exhibit a high level of consistency $(0.15 \%)$ on the Siberian Territory. The tidal load vectors agree within $1 \mathrm{nms}^{-2}$. A mean of the different load vectors will provide the most precise corrections, except in the area of the Sakhalin Island, where the most recent models fit better the observations. The final conclusion is that gravity tides predictions, based on the mean of the most recent ocean tides models, have a precision of the order of $5 \mathrm{~nm} / \mathrm{s}^{2}$ on the Siberian territory.

Keywords: Tidal gravity observations, ocean tides models, tidal predictions

\section{Introduction}

Tidal gravity recording is an efficient tool for the comparison of different ocean tides models by determining how the computed ocean tides loading effects fit the observations. It is then possible to recommend one or several models for tidal gravity prediction.

The observations have been performed with LaCoste \& Romberg (LCR) gravimeter G402. The gravimeter is equipped with a MVR feedback system (van Ruymbeke et al., 1995) providing a frequency modulated signal. The frequency is counted during one minute by a microprocessor controlled MICRODAS system (van Ruymbeke et al., 1995). The data are stored on computer. Temperature and pressure were recorded in the room using an EDAS system (van Ruymbeke et al., 1999). The pre-processing is made using the interactive Tsoft software (Van Camp and Vauterin, 2005). The data are decimated to one hour ordinates for a classical tidal analysis using the ETERNA3.4 software (ANALYZE, Wenzel, 1996) or the VAV04 program (Venedikov et al., 2001, 2003).

For the main diurnal (D) and Semi-Diurnal (SD) tidal waves we determine the , observed amplitude A and the phase difference $\alpha$ with respect to the astronomical tide, i.e. the vector $\mathbf{A}=(\mathrm{A}, \alpha)$ in polar coordinates. All vectors will be expressed in polar coordinates. The amplitude factor $\delta$ is defined as the ratio $A / A_{\text {th }}$ (Melchior, 1983) with respect to the astronomical tide of amplitude $A_{\text {th }}$.

We build the modelled tidal factors based on the body tide amplitude $\mathbf{R}\left(\mathrm{R}=\mathrm{A}_{\text {th. }} . \delta_{\text {model }}, 0\right)$, where $\delta_{\text {model }}$ is the amplitude factor computed using a model of 
the response of the Earth to the tidal force, and the ocean load vector $\mathbf{L}(L, \lambda)$ computed from different ocean tides models. The modelled vector $\mathbf{A}_{\mathbf{m}}\left(\mathrm{A}_{\mathrm{m}}, \boldsymbol{\alpha}_{\mathrm{m}}\right)$ is given as

$$
\mathbf{A}_{\mathbf{m}}=\mathbf{R}+\mathbf{L}
$$

The modelled amplitude factor $\delta_{\mathrm{m}}$ is simply given by the ratio $\mathrm{A}_{\mathrm{m}} / \mathrm{A}_{\mathrm{th}}$.

The $\mathbf{R}$ vector depends on the choice of the body tides model describing the response of the Earth to the tidal forces. Dehant et al., 1999 proposed two different models the elastic one and the non-hydrostatic/anelastic one. The MAT01 model (Mathews, 2001) provides amplitude factors very close to the DDW99 anelastic/non-hydrostatic one. The discrepancy between the elastic and anelastic models is at the level of $0.15 \%$. On the grounds of previous comparisons between the two models (Baker and Bos, 2003, Ducarme et al., 2006), based on the superconducting gravimeter array (Global Geodynamics Project, Crossley et al., 1999), we decided to use the DDW99 non-hydrostatic/anelastic model as a standard. In our final error budget we consider that the uncertainty associated with the choice of the model is at the level of $0.1 \%$ (Ducarme $\&$ al., 2006).

The modelled tidal factors $A_{m}$ and $\alpha_{m}$ are usually used to compute gravity tides predictions (Zahran et al., 2005) and one of the main goals of this work is to assess the accuracy of such tidal predictions across Siberia. It is an important topic as absolute gravity measurements are routinely performed in the area for tectonic activity monitoring (Stus et al., 1995; Kalish et al., 2002; Arnautov et al., 2007). The other main goal of our work is to test different ocean tides models. We can directly compare the vectors $\mathbf{A}$ and $\mathbf{A}_{\mathbf{m}}$ to evaluate the adequacy of the corresponding ocean tides model. With this approach we can separate the calibration of the instrument acting on the amplitude factor A from the instrumental delay and timing error affecting only the phase $\alpha$.

The precise determination of Long Period (LP) tides is only possible using very long registrations of gravimeters with a very low drift rate such as Superconducting Gravimeters. In our Trans Siberian Profile (TSP) we did not meet these requirements so that we shall select the best LP models on the grounds of previous studies (Ducarme et al, 2004; Boy et al, 2006).

\section{Figure 1 and Table 1}

The TSP is crossing Siberia from Novosibirsk to Sakhalin (Table 1 and Figure 1). A first station was installed in 1996 at the Talaya underground laboratory close to the Baikal. In 1997 the instrument returned to Brussels for update and a new series of observations started in 2001. The second station was installed in a geophysical observatory located at Zabaikalskoe, not far from Khabarovsk city, some $300 \mathrm{~km}$ away from the Pacific Ocean. The gravimeter LCR402 was installed in a small building and the temperature of the room was controlled by means of an electrical heating system. However in winter time there were frequent power interruptions and in summer the temperature in the gravimeter room rose sometimes above the reference temperature of the thermostat (Timofeev et al., 2006). These portions of the record had to be eliminated. It explains why 
there are only 400 used days in two and a half year. Novosibirsk/Klutchi is a permanent seismic and tidal gravity station (Saritcheva et al., 1998). The gravimeter was installed in 2003 on a pillar located in a temperature controlled room with double insulation. In Yuzhno Sakhalinsk, the gravimeter was installed in the basement of the Institute of Marine Geodesy and Geophysics.

After discussion of the calibration of the instrument, we consider the inner consistency of the tidal loading predictions. We compare the observations with the modelled tidal factors, discuss the problem of the LP tides and evaluate the accuracy of the tidal gravity predictions in the area.

\section{Calibration of the gravimeter}

The LCR402 took part to the Trans World Tidal gravity Profiles (Melchior and Ducarme, 1980) and its calibration was adjusted to provide at Brussels a tidal amplitude factor 1.161 for O1. Later on it was found that the Brussels reference had to be adjusted from 1.161 to 1.153 (Melchior, 1994), so that, for the station Talaya, we have to impose a normalisation factor 0.993. A short record of 50 days, performed at the beginning of 1998 using the normalisation factor 0.993, gave for $\mathrm{O} 1$ at Brussels a value $\left(\delta=1.154 \pm .014, \alpha=-0.19^{\circ} \pm 0.72^{\circ}\right)$, in agreement with the new Brussels reference. After modification of the electronics of the instrument, tidal records were performed in Brussels at the beginning and at the end of the second observation campaign in 2001 and 2005. The results are given in Table 2. With respect to the Brussels standard represented by the analysis of the superconducting gravimeter T003, the mean of the two registration periods agrees within the RMS error for the M2 wave, which is the most precisely determined. It is thus not suitable to modify the maker dial calibration constant $\mathrm{K}$ provided by the maker. The overall uncertainty on the calibration of the instrument is close to $0.25 \%$, including the $0.2 \%$ uncertainty on the Brussels reference system (Ducarme and Somerhausen, 1997).

\section{Table 2}

The dial calibration constant $\mathrm{K}$ expresses the force applied to the beam of the gravimeter by a unit rotation of the dial and is usually expressed in $\mathrm{nms}^{-2} /$ (dial division). On the other hand we have to transform the output of the MICRODAS system in equivalent acceleration applied to the beam i.e. determine the scale calibration C in [physical units] per [recording units] or in our case in $\mathrm{nms}^{-2} / \mathrm{Hz}$. The usual way of calibrating an instrument, i.e. determining the value of $C$, is to perform a displacement of $m$ divisions of the micrometric screw. The force applied to the gravimeter is then $F=K m$. If the amplitude of the response of the instrument is $l$, the calibration of the instrument is then

$$
C=F / l=K / d
$$

where $d=l / m$ is the reaction of the instrument in $\mathrm{Hz}$ per dial division. Unfortunately, the calibration of a LCR gravimeter equipped with an electronic feedback shows fluctuations of a few per cent (van Ruymbeke, 1998). To check the evolution of the sensitivity during the tidal records calibration sessions were regularly performed using the usual ramp procedure by steps of 10 dial divisions of the micrometer (van Ruymbeke, 1998). An example of calibration session at the 
station Khabarovsk/Zabailalskoe is given in Figure 2. The reaction of the instrument $\mathrm{d}$ in $\mathrm{Hz} /($ dial division) is computed by the option Tides/calibration (spring grav.) of T-soft (Van Camp and Vauterin, 2005). The calibration is generally linearly interpolated between successive calibration sessions, but for the TSP we computed smoothed calibration tables (Ducarme, 1970) to follow the sensitivity variations between the calibrations.

\section{Figure 2}

\section{Ocean tides loading computation}

The ocean tides regime is mixed $\mathrm{D} / \mathrm{SD}$ in the Pacific Ocean close to Kamchatka, Kouriles and Sakhalin Islands. The ocean tides loading effect is larger in the D band than in the SD one everywhere along our profile. For the stations close to the Pacific coast, Khabarovsk and Yusno Sakhalin, the loading affects strongly the phases. Even in Novosibirsk and Talaya, which are continental stations, there is still a noticeable ocean tides loading. As there is no local influence for these stations, the differences between the loading predictions are due to model differences in the far-field of the stations.

As early as 1979, Schwiderski constructed ocean tide models (SCW80, Schwiderski, 1980) by the method of hydrodynamic interpolation with assimilation of tide gauge data on coast lines and islands. He provided for the fist time relatively complete and basic ocean tidal model for loading prediction in geodesy and geophysics. Since 1994, a series of new ocean tidal models have been developed based mainly on the Topex/Poseidon (T/P) satellite altimeter data. In the first generation of models let us quote CSR3 (Eanes and Bettadpur, 1995), FES95 (Le Provost et al., 1995), ORI96 (Matsumoto et al., 1995) and TPX02 (Egbert et al., 1994). These models were extensively tested in Shum et al., 1997. Most of the more recent ones cited hereafter represent updates of the previous ones: CSR4, NAO99 (Matsumoto et al., 2000), GOT00 (Ray, 1999), FES02 and TPX06. All these models provide the principal D and SD waves (Q1,O1,P1,K1,N2,M2,S2,K2) and some of them the LP tides Mf and Mm. An important difference between models is the grid size which has been progressively refined from $\left(1^{\circ} \times 1^{\circ}\right)$ for SCW80, to $\left(0.5^{\circ} \times 0.5^{\circ}\right)$ for CSR3, CSR4, FES95, GOT00, NAO99, ORI96 and finally $\left(0.25^{\circ} \times 0.25^{\circ}\right)$ for FES02 and TPX06. As a result the approximation of the real shape of the coast was steadily improved. A second improvement concerns the global water mass balance during one tidal cycle. It is never perfectly achieved but was also continuously improved.

The tidal loading vector $\mathbf{L}$, which takes into account the direct attraction of the water masses, the flexion of the ground and the associated change of potential, was evaluated by performing a convolution integral between the ocean tide models and the load Green's function computed by Farrell (1972). The Green's functions are tabulated according to the angular distance between the station and the load. The water mass is condensed at the centre of each cell and the Green's function is interpolated according to the angular distance. This computation is rather delicate for coastal stations and models computed on a coarse grid, as the station can be located very close to the centre of the cell. The numerical effect can be largely overestimated. To avoid this problem our tidal loading computation checks the 
position of the station with respect to the centre of the grid. If the station is located inside the cell, this cell is eliminated from the integration and the result is considered as not reliable (Melchior et al., 1980). Fortunately such a situation is not existing in Yuzhno Sakhalinsk, the only station rather close to the sea (35km).

There are several sets of load Green's functions associated with different Earth models, but the Farrell's functions using the Guttenberg-Bullen Earth model are generally used as a standard. The main difference between the tabulated functions appears for loads applied at a very short angular distance, where different models of the crust can produce significant discrepancies. This problem is not addressed here but is critical only for coastal stations.

In connection with the imperfect mass conservation during one tidal cycle, we consider two groups of models, the 4 older models until 1996 (SCW80, CSR3, FES95 and ORI96) on the one hand and the 5 more recent ones (CSR4, NAO99, GOT00, FES02 and TPX06) on the other. For the first generation of models the mass conservation is poorer and we try to re-allocate the mass bias by means of the code developed at the Royal Observatory of Belgium (Melchior et al., 1980). Following Zahran (2000) suggestion we computed also mean tidal loadings for different combinations of models.

Figures 3,4 and 5

\section{Comparison of ocean tides predictions}

We present in Figures 3, 4 and 5 a direct comparison of the modelled tidal amplitude in a $\mathrm{X}-\mathrm{Y}$ diagram, where the $\mathrm{X}$ axis corresponds to the in phase component $\left(\mathrm{A}_{\text {mod }} \cos \left(\alpha_{\text {mod }}\right)\right)$ and the $\mathrm{Y}$ axis to the out-phase component $\left(\mathrm{A}_{\bmod }\right.$ $\sin \left(\alpha_{\text {mod }}\right)$. The theoretical tidal amplitude at each station (Table 1$)$ has been subtracted from the $\mathrm{X}$ component. The radius of the circle representing the observations it scaled on $1 \mathrm{nms}^{-2}$. For $\mathrm{O} 1$ and $\mathrm{K} 1$ all the models agree in all the stations within $\pm 1 \mathrm{nms}^{-2}$ i.e. $0.3 \%$ and $0.25 \%$ on the amplitude factor or $0.17^{\circ}$ and $0.14^{\circ}$ on the phase difference respectively. For M2 the dispersion in the out of phase component is larger at the two stations closer to the Pacific Ocean. At Yuzhno-Sakhalinsk the 4 older models (symbols with white background) are offset with respect to the 5 more recent ones.

The standard deviations of the modelled amplitude factors and phase differences computed with the 9 selected ocean tides models (Table 3) are very similar in all the stations, close of $0.0012\left(0.079^{\circ}\right)$ for $01,0.0008\left(0.046^{\circ}\right)$ for $\mathrm{K} 1$ and 0.0018 $\left(0.099^{\circ}\right)$ for $\mathrm{M} 2$. For $\mathrm{O} 1$ and $\mathrm{K} 1$ the ratio of the standard deviations corresponds to the inverse of the amplitude ratio of the tidal waves. The modelling of M2, which has amplitude similar to $\mathrm{O} 1$, seems less stable. It is due to the fact that the SD waves are more turbulent than the D ones.

Another interesting comparison of the stability of the ocean tides loading computation is to follow the results obtained with a given family of models. We have indeed 4 versions of FES models, i.e. 95, 99, 02 and 04 . The resolution of the grid is $0.5^{\circ} \times 0.5^{\circ}$ for FES95, $0.25^{\circ} \times 0.25^{\circ}$ for FES99 and FES02, while it reaches $0.125^{\circ} \times 0.125^{\circ}$ for FES04. Looking at the results of Table 4, one notices immediately the large standard deviation on the M2 phase at Yuzhno Sakhalinsk. A 
closer look shows that it is due to FES99. Moreover the amplitude factor of M2 is systematically too low using FES99 model. It is a reason why we did not use FES99 for our general comparison. Considering the standard deviations in Table 4 it seems that the variations inside a given family of models can be of the same magnitude as the variations inside the global set of 9 models (Table 3).

\section{Tables 3 and 4}

\section{The Tidal Analysis Results}

The observations were routinely analysed by means of the ETERNA and VAV programs, with very similar results. One interesting feature of VAV is its ability to automatically detect and eliminate perturbed portions of the data, based on the following principles. VAV is replacing the directly observed hourly ordinates by filtered numbers $U(T)$, computed at time $T=0, \Delta T, 2 \Delta T, \ldots$, where the time step $\Delta T$ is the length of the filters used. The results here discussed we use $\Delta T=48^{h}$. VAV computes the residuals $\Delta U(T)$ of the filtered numbers and estimates their variance $\sigma_{U}^{2}$. In the case $U(T)$ are without particular anomalies and they have normal distribution the ratio $t=\Delta U(T) / \sigma_{U}$ should have distribution of Student. Due to this, when $t$ is higher then a threshold $t_{c r i t}$, obtained from the distribution of Student for selected confidence probability $P_{C}$ the corresponding $U(T)$ is eliminated from the processing. As this procedure is generally improving the final agreement between observations and modelling, we present generally in Table 5 the final results obtained using the VAV code. For Khabarovsk detailed considerations can be found in Timofeev et al., 2006.

A general comment is that the observed ratio $\delta(\mathrm{M} 2) / \delta(\mathrm{O} 1)$, which is independent from the calibration of the instrument, is generally lower than the modelled one. It could be due to a systematic instrumental perturbation in the diurnal band, related to temperature effects. It should be pointed out with that respect, that the temperature was well regulated in Novosibirsk and Talaya, where the ratio is too low. Another possibility is that there is a bias between the diurnal and the semidiurnal waves in the ocean tides loading computations $(\mathbf{L})$ and in the body tides model (R). However, as the associated internal error is of the same order as the discrepancy, it is difficult to draw a final conclusion.

To comment on the individual stations we can also refer to the Figures 3 to 5 . The real misfit between observations is directly given by the distance between the observations (open circle) and the symbols representing the modelled amplitude and phase using the different ocean tides models. The radius of the open circle corresponds to an uncertainty of $1 \mathrm{nms}^{-2}$, i.e. close to $0.3 \%$ for $\mathrm{O} 1$ and M2 and $0.25 \%$ on $\mathrm{K} 1$. This radius corresponds also to the discrepancy between the modelled tidal factors (section 4).

The best global agreement is obtained on M2. In Yuzhno Sakhalinsk the observations are closer to the 5 more recent models and FES95 is largely offset. It is a reason why it has been omitted in the MEAN in Table 5. Yuzhno sakhalinsk is the only station where a group of models is definitely better. For K1, which has the largest amplitude the agreement is good, except in Yuzhno Sakhalinsk, where the 
observed tidal vector has a large phase offset. As a matter of fact the useful time span in this station was too short to allow an effective separation between $\mathrm{K} 1$ and the meteorological wave S1, which has a period of one solar day. For O1 the precision is lower indeed, with a tendency of a phase lag of the observations with respect to the models.

To summarize, the discrepancy is $1.5 \mathrm{nms}^{-2}$ for $\mathrm{O} 1$ (Talaya excepted), $1 \mathrm{nms}^{-2}$ for K1 (Yuzhno Sakhalinsk excepted) and $1 \mathrm{nms}^{-2}$ for M2.

\section{Table 5}

\section{Modelling the LP tides}

Two recent studies (Ducarme et al, 2004; Boy et al, 2006) showed that, for the fortnightly lunar wave Mf, the tidal loading computations based on recent ocean tides models were in agreement with tidal gravity observations of superconducting gravimeters performed in the frame of the Global Geodynamics Program (Crossley et al, 1999). Boy et al, 2006 showed that the recent ocean tides models NAO99, TPX06 and FES02 are in good agreement and definitely better than the old SCW80 one. Ducarme et al, 2004 showed that in Europe, for the same latitude range as in Siberia, the agreement between observations and modelling with NAO99 is better than $0.5 \%$ i.e. $2.5 \mathrm{~nm} / \mathrm{s}^{-2}$. It corresponds to the RMS error on the experimental determination of the tidal factors. In Membach (Belgium) the tidal loading vector $\mathbf{L}$ determined with NAO99 explains $90 \%$ of the discrepancy between observations and body tide models. The observations cannot determine precisely enough the monthly lunar wave Mm so that it is not yet possible to confirm its modelling. However Boy et al. showed that the ratio of the amplitude of the tidal loading vectors of $\mathrm{Mm}$ and $\mathrm{Mf}$ is roughly equal to their amplitude ratio in the tidal potential and that the phases are similar. We can thus include Mm and Mf in one and a same group. The 3 recent models (NAO99, TPX06, FES04) agree closely with a standard deviation better than $0.1 \%$ in amplitude and $0.15^{\circ}$ phase i.e. lower than $0.05 \mathrm{nms}^{-2}$ (Table 6).

For the annual and semi-annual solar waves Sa and Ssa the tidal loading is not the main perturbation. The contributions from meteorological and hydrological sources are preponderant. Tidal gravity analyses Superconducting Gravimeters data determined observed tidal factor larger than 2 for Sa (Ducarme et al, 2006), while global models are required for effective pressure corrections (Neumeyer et al., 2004). Continental water storage fluctuations induce strong seasonal effects (Peter et al, 1995; Neumeyer et al, 2006). As these very long period tidal waves are only important for absolute gravity measurements and deserve a special treatment we suggest to use the body tides model values for tidal predictions.

The constant tidal effect called MOS0 should be treated with a special care in order to follow the resolutions of the International Association of Geodesy (IAG). In gravimetry one should follow the "zero tide" correction principle i.e. one should remove only the astronomical part of the MOS0 tide and not the constant deformation. Clearly speaking the amplitude factor of MOS0 should be put equal to one.

Table 6 


\section{Discussion and conclusions}

On the Siberian territory the tidal factors modeled using 9 different ocean tides models have a standard deviation close to $0.1 \%\left(0.05^{\circ}\right)$ for the diurnal waves and $0.2 \%\left(0.1^{\circ}\right)$ for $\mathrm{M} 2$. The individual models agree within $1 \mathrm{nms}^{-2}$, except in Yuzhno Sakhalinsk, which is very close to the Pacific Ocean.

For M2, the discrepancy between the observed tidal vector and the modelled ones is lower than $1 . \mathrm{nms}^{-2}$. It corresponds to $0.3 \%$ of the wave amplitude. For the diurnal waves the discrepancies are generally at the level of $1.5 \mathrm{nms}^{-2}(\mathrm{O} 1)$ and $1 . \mathrm{nms}^{-2}(\mathrm{~K} 1)$. It is roughly inversely proportional to the wave amplitude in the tidal potential. The statement made in section 2, i.e. that the calibration of the gravimeter is stable and correct at the level of $0.25 \%$, is not contradicted.

Given the RMS errors on the analysis results, our observations cannot discriminate the best ocean tides models inside the Siberian territory. The modeling of the tidal gravity factors using the recent ocean tides models has already reached the level of accuracy obtained by tidal gravity records with standard spring gravimeters, at least at a distance of a few hundred kilometers from the coast. In Yuzhno Sakhalinsk, the recent models CSR4, FES02, GOT00, NAO99 and TPX06, provide a better agreement with the observations for $\mathrm{O} 1$ and M2.

For tidal gravity predictions we can model the principal D and SD waves, i.e. Q1, O1, P1, K1, N2, M2 ,S2, K2, as well as Mf. Using the mean of 9 ocean tides models we can insure a precision of $0.03 \%\left(0.015^{\circ}\right)$ and $0.06 \%\left(0.03^{\circ}\right)$ for the $\mathrm{D}$ and SD waves respectively. For what concerns the long period tides, the recent models are significantly improved for the lunar tides Mf (better than 0.04\%, $0.08^{\circ}$ ) and $\mathrm{Mm}$, but it should be necessary to take into account the seasonal influence of continental water storage changes for the modelling of the annual Sa and semiannual Ssa tides. Let us consider the modelled tidal factors at the station Sakhalinsk, using the mean of the 5 most recent models for the D and SD tides and of 3 models for LP tides. The modelling errors of this station are the largest inside the TSP as the loading is maximum. The D and SD waves have a contribution of $2,000 \mathrm{nms}^{-2}$ and $1,000 \mathrm{nms}^{-2}$ respectively. Given the precision on the mean of 5 maps deduced from the standard deviations of the modelled tidal factors (Table 3), the RMS error in each band can reach $0.9 \mathrm{nms}^{-2}$. With a peak to peak amplitude of $150 \mathrm{nms}^{-2}$ the RMS error on the LP tides, computed from Table 6, will be lower than $0.05 \mathrm{nms}^{-2}$. The global RMS error due to load computations will thus reach $1.3 \mathrm{nms}^{-2}(0.05 \%$ of the tidal range). On the Siberian territory the RMS error on the tidal prediction, including body tides model uncertainty $(0.1 \%)$ and tidal loading error, will be well below $0.15 \%$ or $4 \mathrm{nms}^{-2}$. The uncertainty on the body tides model is thus the largest error source. As the tidal loading corrections are very well constrained inside the Siberian territory, this area is a suitable location for the installation of a tidal gravimeter calibrated with accuracy better than $0.1 \%$, in order to discriminate the different body tides models.

\section{Acknowledgements}


The tidal gravity observations have been performed in the framework of the Scientific and Technical Agreements between Belgium and the Russian Federation (convention BL/33/R09).

\section{Bibliography}

Arnautov G.P., Kalish E.N., Stus Y.F., Smirnov M.G. (2007) Monitoring of gravity variation by modern ballistic gravimeter, Proceedings of GEO-SIBERIA, III International congress, 25-27 April 2007, Novosibirsk, 3, 236-241.

Baker TF, Bos MF (2001) Tidal gravity observations and ocean tides models. Proc. $14^{\text {th }}$ Int. Symp. on Earth Tides, , J. Geodetic Soc. of Japan, 47, 1, 76-81. Baker TF, Bos MS (2003) Validating Earth and ocean models using tidal gravity measurements. Geophys. J. Int., 152, 468-485.

Boy J.P., LLubes M., Ray R., Hinderer J., Florsch N. (2006) Validation of longperiod oceanic tidal models with superconducting gravimeters. J. of Geodynamics, 41, 112-118.

Crossley, D., Hinderer, J., Casula G., Francis O., Hsu, H.T., Imanishi, Y., Jentzsch G., Kääriäinen J., Merriam, J., Meurers B., Neumeyer J., Richter B., Shibuya K., Sato T., Van Dam T. (1999) Network of superconducting gravimeters benefits a number of disciplines. EOS, 80, 11, 121/125-126.

Dehant V, Defraigne P, Wahr J (1999) Tides for a convective Earth. J. Geoph.

Res., 104, B1, 1035-1058.

Ducarme B. (1970) Sensitivity smoothing before the analysis of tidal data. Bull. Inf. Marées Terrestres, 81, 4962-4981.

Ducarme B., Somerhausen A. (1997) Tidal gravity recording at Brussels with a SCINTREX CG-3M gravimeter. Bull. Inf. Marées Terrestres 126, 9611-9634.

Ducarme B., Venedikov A. P., Arnoso J., Vieira R. (2004) Determination of the long period tidal waves in the GGP superconducting gravity data. J. of

Geodynamics, 38, 307-324

Ducarme B., Vandercoilden L., Venedikov A.P., 2006. The analysis of LP waves and polar motion effects by ETERNA and VAV methods. Bulletin Inf. Marées Terrestres, 141, 11201-11210.

Ducarme B., Sun H. P., Xu J. Q. (2006) Determination of the free core nutation period from tidal gravity observations of the GGP superconducting gravimeter network. Journal of Geodesy DOI: 10.1007/s00190-006-0098-9.

Eanes RJ, Bettadpur, SV (1995) The CSR 3.0 Global Ocean Tide Model: Diurnal and Semi-diurnal Ocean Tides from TOPEX/POSEIDON Altimetry, CSR Technical Memorandum 95-06, center for Space Research, The University of Texas at Austin, Austin, Texas, USA.

El Wahabi A., Ducarme B., van Ruymbeke M. (2001) Humidity and temperatura effects on La Coste \& Romberg gravimeters. Proc. $14^{\text {th }}$ Int. Symp. on Earth Tides, , J. Geodetic Soc. of Japan, 47, 1, 10-15. 
Egbert, G., Bennett, A., Foreman, M. (1994): TOPEX/Poseidon tides estimated using a global inverse model. Journal of Geophysical Research, 99(C12), 2482124852.

Farrell WE (1972) Deformation of the Earth by surface load. Rev. Geophys., 10, 761-779.

Kalish E., Arnautov G., Ducarme B., Smirnov M., Stus Y., Timofeev V., 2000 Gravity variations at Novosibirsk and Irkutsk regions by Gabl-M measurements Proc. Workshop “ High Precision Gravity Measurements with Application to Geodynamics", Walferdange, 34-26 mars 1999. Cahiers Centre Eur. Geod. et Séismologie 17, 187-192

Le Provost C, Genco ML, Lyard F (1994) Spectroscopy of the ocean tides from a finite element hydrodynamic model, J. Geophysical Research, 99 (C12), 2477724797.

Mathews, P.M. (2001): Love numbers and gravimetric factor for diurnal tides. Proc. 14th Int. Symp. on Earth Tides, Journal of the Geodetic Society of Japan, 47, 1, 231-236.

Matsumoto K, Ooe M, Sato T et al. (1995) Ocean tides model obtained from TOPEX/POSEIDON altimeter data. J. Geophys. Res., 100, 25319-25330.

Matsumoto, K., Takanezawa, T., Ooe, M. (2000): Ocean tide models developed by assimilating TOPEX/POSEIDON altimeter data into hydrodynamical model: a global model and a regional model around Japan. J. Oceanography, 56, 567-581. Melchior P (1983) The tides of the planet Earth, 2nd ed. Pergamon Press, Oxford, $641 \mathrm{pp}$.

Melchior P (1994). A new data bank for tidal gravity measurements (DB92). Physics Earth Planet. Interiors, 82, 125-155.

Melchior P., Ducarme B. (1980) Tidal Gravity Profiles 1973-1980. Bull. Inf. Marées Yerrestres, Obs. Royal de Belgique, IV, 5, 47-62.

Melchior P., Moens M., Ducarme B. (1980): Computations of tidal gravity loading and attraction effects. Bull Obs. Marées Terrestres, Obs. Roy. Belg., 4, 5, 95-133. Melchior P, Francis O. (1996) Comparison of recent ocean tide models using ground-based tidal gravity measurements, Marine Geodesy, 19, 291-330. Neumeyer J., Hagedorn J., Leitloff J., Schmidt T. (2004) Gravity reduction with three-dimensional atmospheric pressure data for precise ground gravity measurements. Journal of Geodynamics, 38, 437-450

Neumeyer J., Barthelmes F., Dierks O., Flechtner F., Harnisch M., Harnisch G., Hinderer J., Imanishi Y., Kroner C., Meurers B., Petrovic S., Reigber Ch., Schmidt R., Schwintzer P., Sun H.-P., Virtanen H. (2006) Combination of temporal gravity variations resulting from Superconducting Gravimeter recordings, GRACE satellite observations and global hydrology models. Journal of Geodesy, doi:

10.1007/S00190-005-0014-8.

Peter G., Klopping F.J., Berstis K.J., (1995) Observing and modeling gravity changes caused by soil moisture and groudwater table variations with superconducting gravimeters in Richmond, Florida, U.S.A.. Cahiers du Centre Européen de Géodynamique et de Séismologie, 11, 147-158

Ray, R.D. (1999): A global ocean tide model from TOPEX/POSEIDON altimetry: GOT99. NASA Tech. Mem. 209478, Goddard Space Flight Centre, Greenbelt, MD, USA 
Saritcheva J. K., Timofeev V. Y., Khomoutov S. J. (1998) The results of tidal observations in Novosibirsk (1991-1996). Proc. 13th Int. Symp. On Earth Tides, Brussels, July 22-25, 1997. P. Pâquet \& B. Ducarme eds., Observatoire Royal de Belgique, Série Géophysique, Bruxelles.

Schwiderski EW (1980) On charting global ocean tides, Rev. Geophys. Space Phys., 18: 243-268.

Shum CK, Andersen OB, Egbert, G (1997) Comparison of Newly Available Deep Ocean Tide Models by the TOPEX/POSEIDON Science Working Team, J.

Geophys. Res., 102 (C11), 25173-25194.

Stus Y.F., Arnautov G.P., Kalish E.N., Timofeev V.Y. (1995) Non-tidal Gravity variation and Geodynamic Process. // "Gravity and Geoid", Shpringer, Germany, 35-43.

Tamura Y., 1987: A harmonic development of the tide-generating potential. Bull. Inf; Marées Terrestres, 99, 6813-6855.

Timofeev V.Y., van Ruymbeke M., Woppelmann G., Everaerts M., Zapreeva E.A., Gornov P.Y., Ducarme B. (2006)Tidal gravity observations in Eastern Siberia and along the Atlantic coast of France. Proc. 15th Int. Symp. On Earth Tides, Journal of Geodynamics, 41, 30-38.

Van Camp M., Vauterin P. (2005) Tsoft: graphical and interactive software for the analysis of time series and Earth tides. Computer \& Geosciences, 31, 631-640. van Ruymbeke M, Somerhausen A, Blanchot G, Claes A, Grammatica N (1995) New developments with gravimeters. Proc. 12th Int. Symp. on Earth Tides, Beijing, August 4-7, 1993. Sciences Press, Beijing-New York, 89-102 . van Ruymbeke M (1998) Internal precision of calibration for LaCoste \& Romberg gravimeters equipped with a feedback system. Proc. 13th Int. Symp. on Earth Tides, Brussels, July 22-25, 1997, Observatoire Royal de Belgique, Série Géophysique, Bruxelles, 59-68.

van Ruymbeke M, Beauducel F, Somerhausen A (1999) The environmental data acquisition system (EDAS) developed at the Royal Observatory of Belgium. Proc. Seminar 192 der WE-Heraeus-Stiftung “Microtemperature Signals of the Earth's Crust”, Bas Honef, Germany, 25-27 March, 1998, 23-35.

Venedikov AP., Arnoso J., Vieira R (2001): Program VAV/2000 for Tidal Analysis of Unevenly Spaced Data with Irregular Drift and Colored Noise. J. Geodetic Society of Japan, 47, 1, 281-286.

Venedikov AP, Arnoso J, Vieira R (2003) VAV: a program for tidal data processing. Computers \&. Geosciences, 29, 487-502.

Wenzel HG (1996) The nanogal software: earth tide data processing package ETERNA 3.30. Bull. Inf. Maréees Terrestres, 124, 9425-9439.

Zahran K.H. (2000): Accuracy assessment of Ocean Tide loading computations for precise geodetic observations. PhD thesis, Universität Hannover.

Zahran K. H., Jentzsch G., Seeber G. (2005) World-wide synthetic tide parameters for gravity and vertical and horizontal displacements. J. Geod., 79, 293-299 
Table 1: Location of the stations, recording periods and astronomical amplitude of the main tidal waves

$\mathrm{N}$ is the number of registration days effectively used for the analysis

\begin{tabular}{|l|c|c|c|c|c|c|c|c|}
\hline \multicolumn{1}{|c|}{ Station } & $\begin{array}{c}\text { Latitu } \\
\text { de } \\
\mathrm{N}\end{array}$ & $\begin{array}{c}\text { Long. } \\
\mathrm{E}\end{array}$ & $\begin{array}{c}\mathrm{H} \\
\mathrm{m}\end{array}$ & Time span & $\mathrm{N}$ & $\begin{array}{c}\mathrm{O} 1 \\
\mathrm{nms}^{-2}\end{array}$ & $\begin{array}{c}\mathrm{K} 1 \\
\mathrm{nms}^{-2}\end{array}$ & $\begin{array}{c}\mathrm{M} 2 \\
\mathrm{nms}^{-2}\end{array}$ \\
\hline $\begin{array}{l}\text { Novosibirsk } \\
\text { (Kluchi) }\end{array}$ & $54^{\circ} 842$ & $83^{\circ} .247$ & 160 & $03 / 10-04 / 09$ & 244 & 292.7 & 411.6 & 249.3 \\
\hline $\begin{array}{l}\text { Talaya } \\
51^{\circ} .681\end{array}$ & $103^{\circ} .644$ & 550 & $96 / 04-97 / 09$ & 413 & 302.4 & 425.2 & 289.0 \\
\hline $\begin{array}{l}\text { Khabarovsk } \\
\text { (Zabaikalskoe) }\end{array}$ & $47^{\circ} .630$ & $134^{\circ} .747$ & 65 & $01 / 04-03 / 10$ & 448 & 309.4 & 435.1 & 341.3 \\
\hline $\begin{array}{l}\text { Yuzhno } \\
\text { Sakhalinsk }\end{array}$ & $47^{\circ} .030$ & $142^{\circ} .717$ & 80 & $04 / 10-05 / 09$ & 144 & 309.9 & 435.8 & 349.1 \\
\hline
\end{tabular}

Table 2: Comparison of tidal parameters in Brussels

$\mathrm{N}$ : number of registration days, $\delta$ : amplitude factor, $\alpha$ : phase difference

\begin{tabular}{|l|c|c|c|c|c|c|}
\hline \multicolumn{1}{|c|}{ gravimeter } & $\mathrm{N}$ & \multicolumn{2}{|c|}{$\mathrm{O} 1$} & \multicolumn{2}{c|}{$\mathrm{M} 2$} & $\mathrm{M} 2 / \mathrm{O} 1$ \\
\hline & & \multicolumn{1}{c|}{$\delta$} & $\alpha\left(^{\circ}\right)$ & \multicolumn{1}{c|}{$\delta$} & $\alpha\left(^{\circ}\right)$ & \\
\hline SG T003 & 5060 & 1.1530 & 0.057 & 1.1834 & 2.711 & 1.0264 \\
\hline & & \pm .0001 & \pm .004 & \pm .0000 & \pm .002 & \pm .0001 \\
\hline LCR402/2001 & 35 & 1.1557 & 0.065 & 1.1823 & 2.744 & 1.0230 \\
\hline & & \pm .0033 & \pm .166 & \pm .0021 & \pm .102 & \pm .0039 \\
\hline LCR402/2005 & 67 & 1.1578 & -0.324 & 1.1860 & 2.684 & 1.0244 \\
\hline & & \pm .0026 & \pm .127 & \pm .0017 & \pm .081 & \pm .0031 \\
\hline MEAN & & 1.1567 & 0.129 & 1.1842 & 2.714 & 1.0238 \\
\hline (2001/2005) & & \pm .0021 & \pm .105 & \pm .0014 & \pm .065 & \pm .0025 \\
\hline
\end{tabular}


Table 3: standard deviation of the tidal factors modelled by 9 different ocean tides models

\begin{tabular}{|l|c|c|c|c|c|c|}
\hline STATION & \multicolumn{2}{|c|}{$\mathrm{O}_{1}$} & \multicolumn{2}{c|}{$\mathrm{K}_{1}$} & \multicolumn{2}{c|}{$\mathrm{M}_{2}$} \\
& $\sigma_{\delta}$ & $\sigma_{\alpha}$ & $\sigma_{\delta}$ & $\sigma_{\alpha}$ & $\sigma_{\delta}$ & $\sigma_{\alpha}$ \\
\hline Novosibirsk & 0.0011 & $0.049^{\circ}$ & 0.0011 & $0.045^{\circ}$ & 0.0018 & $0.094^{\circ}$ \\
\hline Talaya & 0.0010 & $0.068^{\circ}$ & 0.0008 & $0.036^{\circ}$ & 0.0015 & $0.076^{\circ}$ \\
\hline Khabarovsk & 0.0014 & $0.095^{\circ}$ & 0.0008 & $0.039^{\circ}$ & 0.0016 & $0.101^{\circ}$ \\
\hline Y.Sakhalinsk & 0.0012 & $0.095^{\circ}$ & 0.0006 & $0.058^{\circ}$ & 0.0023 & $0.120^{\circ}$ \\
\hline mean & $\mathbf{0 . 0 0 1 2}$ & $\mathbf{0 . 0 7 9}^{\circ}$ & $\mathbf{0 . 0 0 0 8}$ & $\mathbf{0 . 0 4 6}^{\circ}$ & $\mathbf{0 . 0 0 1 8}$ & $\mathbf{0 . 0 9 9}^{\circ}$ \\
\hline
\end{tabular}

Table 4: standard deviation $\sigma$ of the tidal factors modelled using 4 different FES models: 95, 99, 02, 04

\begin{tabular}{|l|c|c|c|c|c|c|}
\hline STATION & \multicolumn{2}{|c|}{$\mathrm{O}_{1}$} & \multicolumn{2}{c|}{$\mathrm{K}_{1}$} & \multicolumn{2}{c|}{$\mathrm{M}_{2}$} \\
& $\sigma_{\delta}$ & $\sigma_{\alpha}$ & $\sigma_{\delta}$ & $\sigma_{\alpha}$ & $\sigma_{\delta}$ & $\sigma_{\alpha}$ \\
\hline Novosibirsk & 0.0005 & $0.058^{\circ}$ & 0.0012 & $0.012^{\circ}$ & 0.0010 & $0.076^{\circ}$ \\
\hline Talaya & 0.0002 & $0.063^{\circ}$ & 0.0011 & $0.025^{\circ}$ & 0.0019 & $0.038^{\circ}$ \\
\hline Khabarovsk & 0.0009 & $0.068^{\circ}$ & 0.0007 & $0.040^{\circ}$ & 0.0020 & $0.097^{\circ}$ \\
\hline Y.Sakhalinsk & 0.0005 & $0.050^{\circ}$ & 0.0010 & $0.048^{\circ}$ & 0.0017 & $0.315^{\circ}$ \\
\hline mean & $\mathbf{0 . 0 0 0 5}$ & $\mathbf{0 . 0 6 0}^{\circ}$ & $\mathbf{0 . 0 0 1 0}$ & $\mathbf{0 . 0 3 1}^{\circ}$ & $\mathbf{0 . 0 0 1 7}$ & $\mathbf{0 . 1 3 1}^{\circ}$ \\
\hline
\end{tabular}


Table 5: Comparison of the modelled tidal factors and the tidal analysis results MEAN 1-4: SCW80, CSR3, ORI96, FES95

MEAN 5-9: CSR4, NAO99, GOT00, FES02, TPX06

a) station Novosibirsk (1289)

\begin{tabular}{|l|c|c|c|c|c|c|c|}
\hline MODEL & \multicolumn{2}{|c|}{$\mathrm{O}_{1}$} & \multicolumn{2}{c|}{$\mathrm{S}_{1} \mathrm{~K}_{1}$} & \multicolumn{2}{c|}{$\mathrm{M}_{2}$} & $\mathrm{M}_{2} / \mathrm{O}_{1}$ \\
\hline$A_{\text {th }}\left(\mathrm{nm} / \mathrm{s}^{2}\right)$ & \multicolumn{2}{|c|}{292.7} & \multicolumn{2}{c|}{411.6} & \multicolumn{2}{c|}{249.3} & \\
\hline & $\delta_{\mathrm{m}}$ & $\alpha_{\mathrm{m}}\left(^{\circ}\right)$ & $\delta_{\mathrm{m}}$ & $\alpha_{\mathrm{m}}\left(^{\circ}\right)$ & $\delta_{\mathrm{m}}$ & $\alpha_{\mathrm{m}}\left(^{\circ}\right)$ & \\
\hline MEAN 1-4 & 1.1540 & 0.303 & 1.1343 & 0.282 & 1.1588 & -0.200 & 1.0041 \\
\hline MEAN 5-9 & 1.1544 & 0.308 & 1.1335 & 0.277 & 1.1606 & -0.261 & 1.0046 \\
\hline OBSERVED & $\delta_{\mathrm{o}}$ & $\alpha_{0}\left(^{\circ}\right)$ & $\delta_{0}$ & $\alpha_{0}\left(^{\circ}\right)$ & $\delta_{0}$ & $\alpha_{0}\left(^{\circ}\right)$ & \\
\hline VAV & $\mathbf{1 . 1 5 8 0}$ & $\mathbf{0 . 1 3 2}$ & $\mathbf{1 . 1 3 6 3}$ & $\mathbf{0 . 2 1 4}$ & $\mathbf{1 . 1 5 9 9}$ & $\mathbf{- 0 . 2 3 0}$ & $\mathbf{1 . 0 0 1 6}$ \\
\hline $12.9 \%^{*}$ & \pm .0039 & \pm .193 & \pm .0030 & \pm .152 & \pm .0037 & \pm .183 & \pm .0054 \\
\hline
\end{tabular}

b) Station Talaya (1301)

\begin{tabular}{|l|c|c|c|c|c|c|c|}
\hline MODEL & \multicolumn{2}{|c|}{$\mathrm{O}_{1}$} & \multicolumn{2}{c|}{$\mathrm{S}_{1} \mathrm{~K}_{1}$} & \multicolumn{2}{c|}{$\mathrm{M}_{2}$} & $\mathrm{M}_{2} / \mathrm{O}_{1}$ \\
\hline$A_{\text {th }}\left(\mathrm{nm} / \mathrm{s}^{2}\right)$ & \multicolumn{2}{|c|}{302.4} & \multicolumn{2}{c|}{425.2} & \multicolumn{2}{c|}{289.0} & \\
\hline & $\delta_{\mathrm{m}}$ & $\alpha_{\mathrm{m}}\left(^{\circ}\right)$ & $\delta_{\mathrm{m}}$ & $\alpha_{\mathrm{m}}\left(^{\circ}\right)$ & $\delta_{\mathrm{m}}$ & $\alpha_{\mathrm{m}}\left(^{\circ}\right)$ & \\
\hline MEAN 1-4 & 1.1592 & 0.398 & 1.1402 & 0.284 & 1.1622 & 0.118 & 1.0026 \\
\hline MEAN 5-9 & 1.1597 & 0.391 & 1.1393 & 0.294 & 1.1629 & 0.054 & 1.0027 \\
\hline OBSERVED & $\delta_{\mathrm{o}}$ & $\alpha_{0}\left(^{\circ}\right)$ & $\delta_{0}$ & $\alpha_{0}\left(^{\circ}\right)$ & $\delta_{0}$ & $\alpha_{0}\left(^{\circ}\right)$ & \\
\hline $4.3 \% *$ & $\mathbf{1 . 1 5 9 8}$ & $\mathbf{0 . 0 1 2}$ & $\mathbf{1 . 1 3 8 6}$ & $\mathbf{0 . 2 6 3}$ & $\mathbf{1 . 1 5 8 5}$ & $\mathbf{0 . 1 0 6}$ & $\mathbf{0 . 9 9 8 9}$ \\
\hline & \pm .0051 & \pm .250 & \pm .0034 & \pm .170 & \pm .0028 & \pm .137 & \pm .0058 \\
\hline
\end{tabular}

c) Station Khabarovsk/Zabaikalskoe (1401)

\begin{tabular}{|l|c|c|c|c|c|c|c|}
\hline MODEL & \multicolumn{2}{|c|}{$\mathrm{O}_{1}$} & \multicolumn{2}{c|}{$\mathrm{K}_{1}$} & \multicolumn{2}{c|}{$\mathrm{M}_{2}$} & $\mathrm{M}_{2} / \mathrm{O}_{1}$ \\
\hline$A_{\text {th }}\left(\mathrm{nm} / \mathrm{s}^{2}\right)$ & \multicolumn{2}{|c|}{309.4} & \multicolumn{2}{c|}{435.08} & \multicolumn{2}{c|}{341.26} & \\
\hline & $\delta_{\mathrm{m}}$ & $\alpha_{\mathrm{m}}\left({ }^{\circ}\right)$ & $\delta_{\mathrm{m}}$ & $\alpha_{\mathrm{m}}\left(^{\circ}\right)$ & $\delta_{\mathrm{m}}$ & $\alpha_{\mathrm{m}}\left(^{\circ}\right)$ & \\
\hline MEAN 1-4 & 1.1842 & 0.866 & 1.1636 & 0.248 & 1.1730 & 0.449 & 0.9905 \\
\hline MEAN 5-9 & 1.1841 & 0.818 & 1.1624 & 0.268 & 1.1718 & 0.403 & 0.9893 \\
\hline OBSERVED & $\delta_{0}$ & $\alpha_{0}\left({ }^{\circ}\right)$ & $\delta_{0}$ & $\alpha_{0}\left(^{\circ}\right)$ & $\delta_{0}$ & $\alpha_{0}\left({ }^{\circ}\right)$ & \\
\hline VAV04 & $\mathbf{1 . 1 8 4 0}$ & $\mathbf{0 . 7 5 0}$ & $\mathbf{1 . 1 6 0 8}$ & $\mathbf{0 . 1 9 1}$ & $\mathbf{1 . 1 7 3 4}$ & $\mathbf{0 . 6 8 0}$ & $\mathbf{0 . 9 9 1 0}$ \\
\hline & \pm .0084 & \pm .406 & \pm .0042 & \pm .208 & \pm .0049 & \pm .239 & \pm .0094 \\
\hline
\end{tabular}

d) station Yuzhno Sakhalinsk (1403)

\begin{tabular}{|l|c|c|c|c|c|c|c|}
\hline MODEL & \multicolumn{2}{|c|}{$\mathrm{O}_{1}$} & \multicolumn{2}{c|}{$\mathrm{K}_{1}$} & \multicolumn{2}{c|}{$\mathrm{M}_{2}$} & $\mathrm{M}_{2} / \mathrm{O}_{1}$ \\
\hline$A_{\text {th }}\left(\mathrm{nm} / \mathrm{s}^{2}\right)$ & \multicolumn{2}{|c|}{309.9} & \multicolumn{2}{c|}{435.8} & \multicolumn{2}{c|}{349.1} & \\
\hline & $\delta_{\mathrm{m}}$ & $\alpha_{\mathrm{m}}\left(^{\circ}\right)$ & $\delta_{\mathrm{m}}$ & $\alpha_{\mathrm{m}}\left(^{\circ}\right)$ & $\delta_{\mathrm{m}}$ & $\alpha_{\mathrm{m}}\left(^{\circ}\right)$ & \\
\hline MEAN 1-3• & 1.2198 & 1.360 & 1.1910 & 0.128 & 1.1813 & 1.625 & 0.9684 \\
\hline MEAN 5-9 & 1.2206 & 1.244 & 1.1909 & 0.160 & 1.1770 & 1.460 & 0.9643 \\
\hline OBSERVED & $\delta_{\mathrm{o}}$ & $\alpha_{0}\left(^{\circ}\right)$ & $\delta_{0}$ & $\alpha_{0}\left(^{\circ}\right)$ & $\delta_{0}$ & $\alpha_{0}\left(^{\circ}\right)$ & \\
\hline VAV04 & $\mathbf{1 . 2 2 3 5}$ & $\mathbf{1 . 1 1 1}$ & $\mathbf{1 . 1 9 3 5}$ & $\mathbf{0 . 7 7 6}$ & $\mathbf{1 . 1 7 5 0}$ & $\mathbf{1 . 5 3 0}$ & $\mathbf{0 . 9 6 0 4}$ \\
\hline $23.2 \% *$ & \pm .0035 & \pm .169 & \pm .0028 & \pm .133 & \pm .0022 & \pm .107 & \pm .0040 \\
\hline
\end{tabular}

-FES95 excluded

* percentage of rejected data by the automatic procedure 
Table 6: Modelled tidal factors for LP wave Mf

\begin{tabular}{|l|c|c|c|c|c|c|c|c|}
\hline & \multicolumn{2}{|c|}{$\begin{array}{c}\text { Novosibirsk } \\
1289\end{array}$} & \multicolumn{2}{c|}{$\begin{array}{c}\text { Talaya } \\
1301\end{array}$} & \multicolumn{2}{c|}{$\begin{array}{c}\text { Khabarovsk } \\
1401\end{array}$} & \multicolumn{2}{c|}{$\begin{array}{c}\text { Y. Sakhalinsk } \\
1403\end{array}$} \\
\hline$A_{\text {th }}\left(\mathrm{nm} / \mathrm{s}^{2}\right)$ & \multicolumn{2}{|c|}{64.47} & \multicolumn{2}{c|}{54.26} & \multicolumn{2}{c|}{40.76} & \multicolumn{2}{c|}{38.75} \\
\hline Model & $\delta_{\mathrm{m}}$ & $\alpha_{\mathrm{m}}\left({ }^{\circ}\right)$ & $\delta_{\mathrm{m}}$ & $\alpha_{\mathrm{m}}\left({ }^{\circ}\right)$ & $\delta_{\mathrm{m}}$ & $\alpha_{\mathrm{m}}\left({ }^{\circ}\right)$ & $\delta_{\mathrm{m}}$ & $\alpha_{\mathrm{m}}\left({ }^{\circ}\right)$ \\
\hline NAO99 & 1.1511 & 0.219 & 1.1503 & 0.154 & 1.1301 & -0.021 & 1.1014 & -0.170 \\
\hline TPX06 & 1.1516 & 0.192 & 1.1509 & 0.109 & 1.1308 & -0.215 & 1.1024 & -0.440 \\
\hline FES04 & 1.1510 & 0.197 & 1.1500 & 0.136 & 1.1303 & -0.074 & 1.1026 & -0.266 \\
\hline MEAN & $\mathbf{1 . 1 5 1 3}$ & $\mathbf{0 . 2 0 3}$ & $\mathbf{1 . 1 5 0 4}$ & $\mathbf{0 . 1 3 3}$ & $\mathbf{1 . 1 3 0 4}$ & $\mathbf{- 0 . 1 0 4}$ & $\mathbf{1 . 1 0 2 2}$ & $\mathbf{- 0 . 2 9 2}$ \\
\hline STD & 0.0004 & 0.015 & 0.0004 & 0.023 & 0.0004 & 0.100 & 0.0006 & 0.137 \\
\hline
\end{tabular}




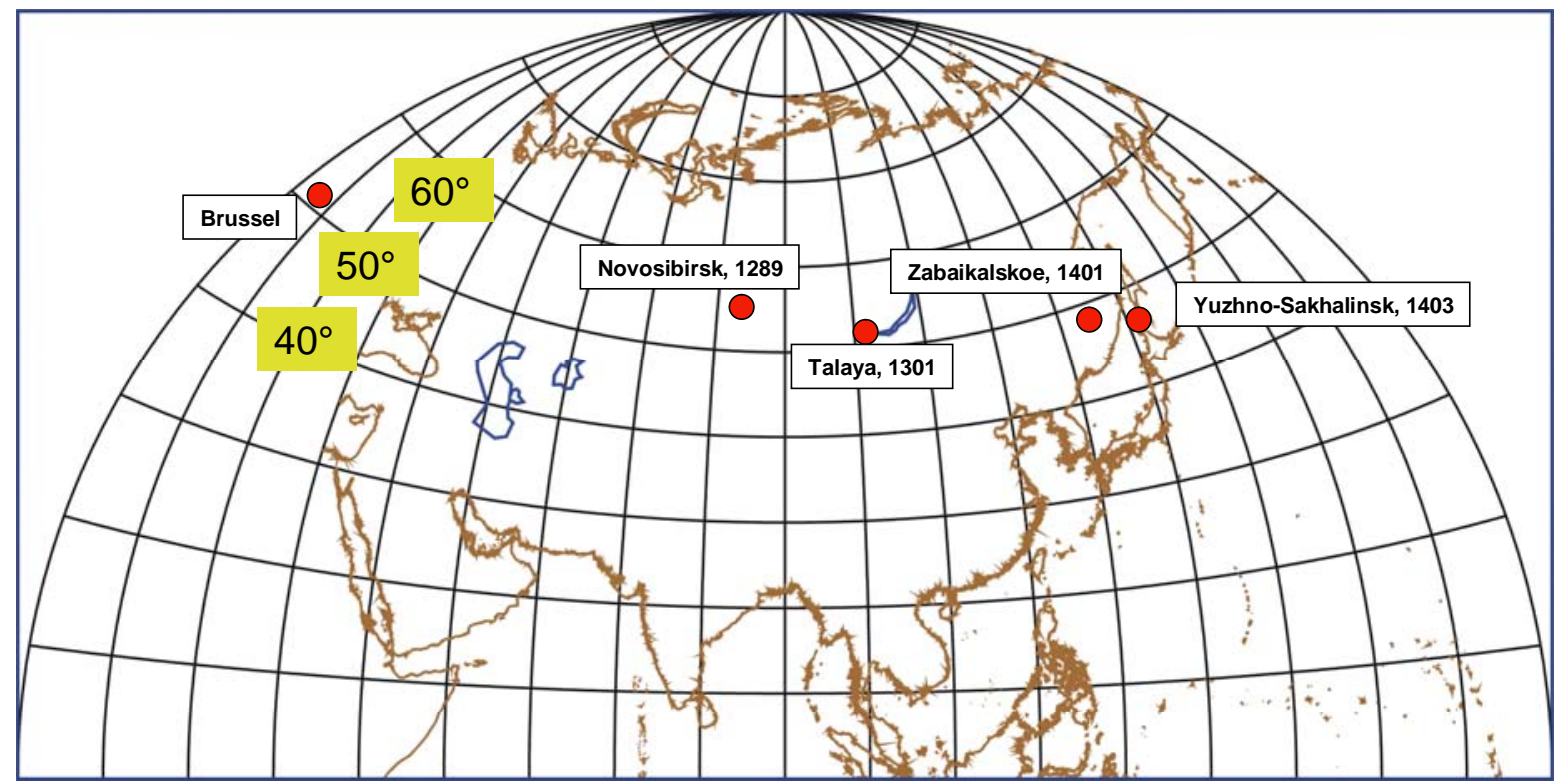

Figure 1. Trans Siberia Tidal Profile and the base station.

From West to East:

Brussels,

Novosibirsk,

Talaya,

Zabaikalskoe, $50.7986^{\circ} \mathrm{N}, \quad 4.3581^{\circ} \mathrm{E}$;

$54.8417^{\circ} \mathrm{N}, 83.2467^{\circ} \mathrm{E}$;

$51.6810^{\circ} \mathrm{N}, 103.6440^{\circ} \mathrm{E}$;

$47.6296^{\circ} \mathrm{N}, 134.7472^{\circ} \mathrm{E}$;

Yuzhno-Sakhalinsk, $47.0297^{\circ} \mathrm{N}, 142.7167^{\circ} \mathrm{E}$. 


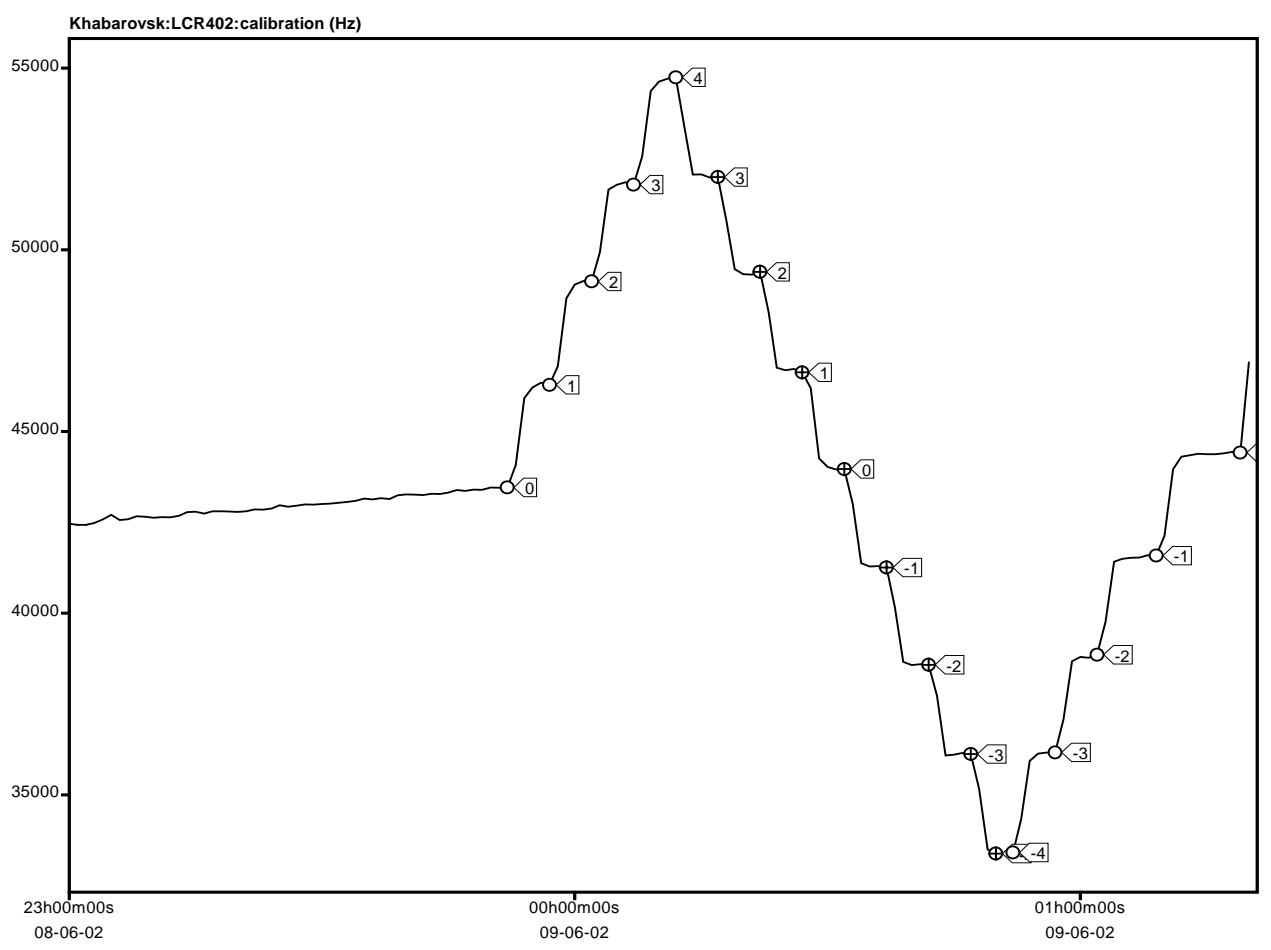

Figure 2: Calibration session by steps of 10 dial divisions on 2002/06/09 at Khabarovsk/Zabailalskoe. The labels indicate the rest position after each step. The instrumental reaction $\mathrm{d}$ is the mean slope of the ramps: $\mathrm{d}=2.718 \pm 0.005 \mathrm{~Hz} / .01$ dial division.

As the dial calibration given by the maker $\mathrm{K}=1.06188 \mathrm{nms}^{-2} / .01$ dial, the scale calibration is given by $\mathrm{C}=\mathrm{K} / \mathrm{d}=0.3907 \mathrm{nms}^{-2} / \mathrm{Hz}$. 


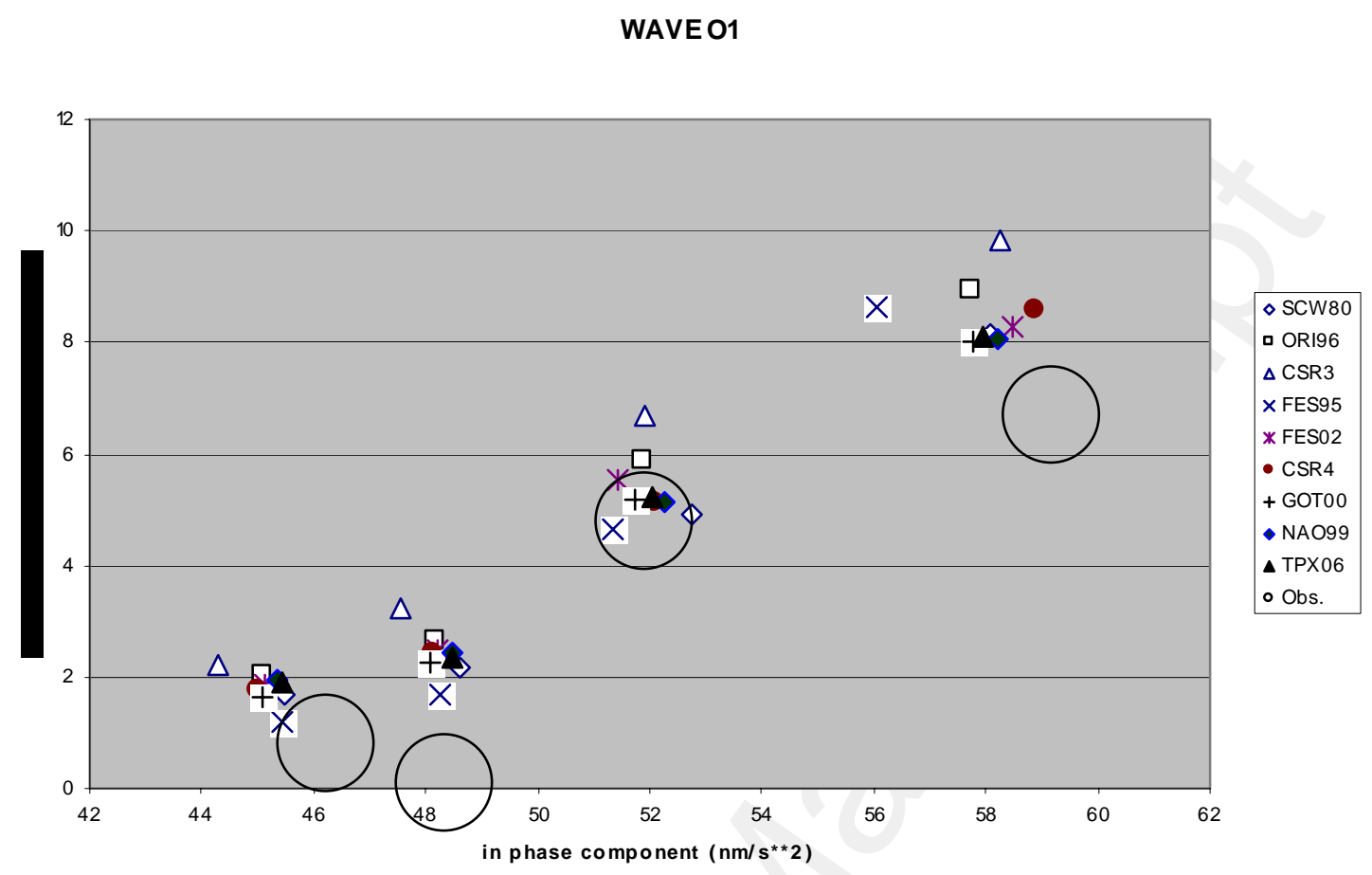

Figure 3: Comparison of the modelled $\mathbf{A}_{\mathbf{m}}$ and observed $\mathbf{A}$ tidal vectors for the wave $\mathrm{O} 1$. The horizontal scale has been adjusted by subtracting the astronomical amplitude $\mathrm{A}_{\text {th }}$ at each station.

From left to right: Novosibirsk (1289), Talaya (1301), Khabarovsk/Zabaikalskoe (1401), Yuzhno Sakhalinsk (1403). 
wave $\mathrm{K} 1$

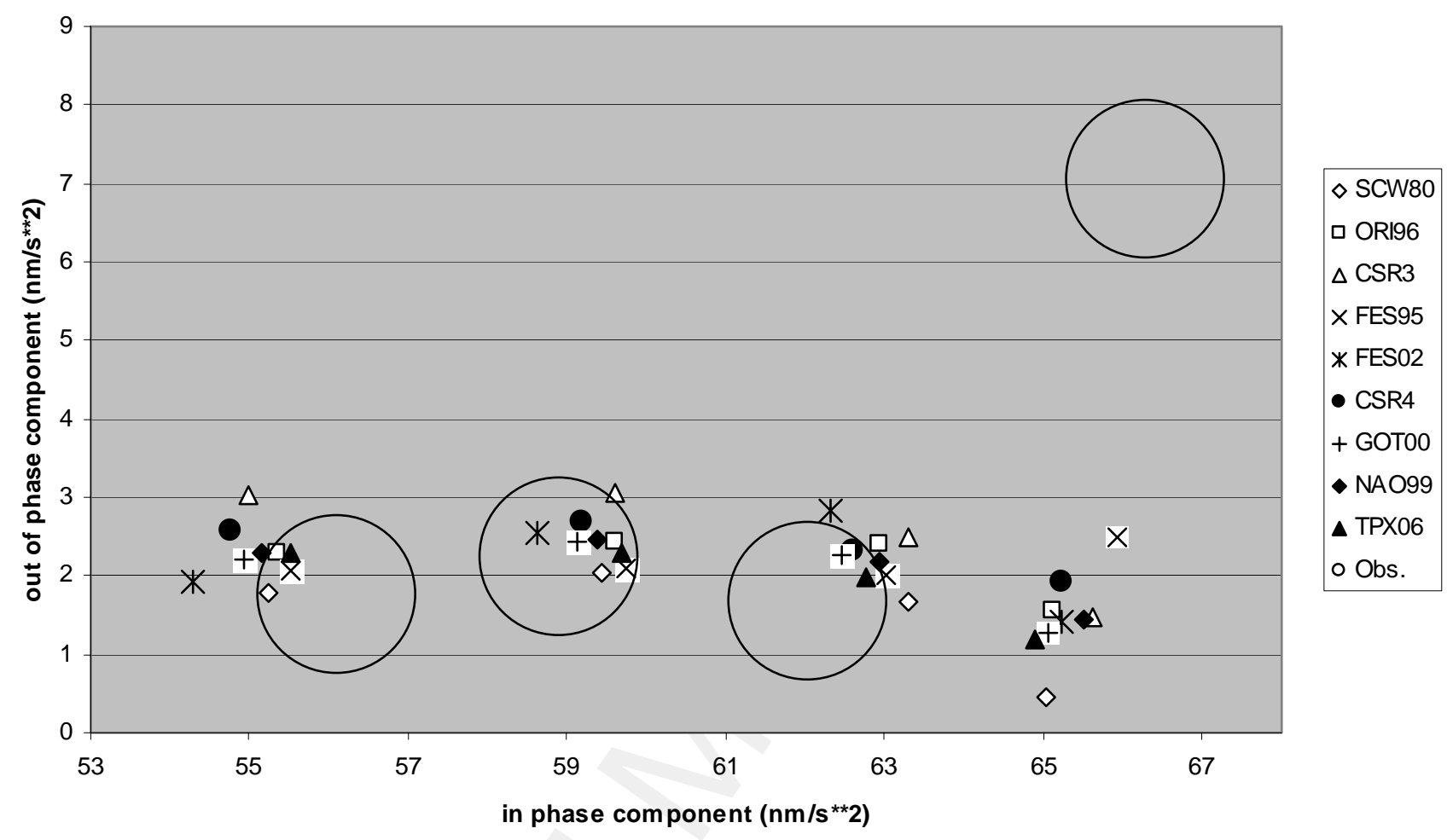

Figure 4: Comparison of the modelled $\mathbf{A}_{\mathbf{m}}$ and observed $\mathbf{A}$ tidal vectors for the wave K1. The horizontal scale has been adjusted by subtracting the astronomical amplitude $\mathrm{A}_{\text {th }}$ at each station.

From left to right: Novosibirsk (1289), Talaya (1301), Khabarovsk/Zabaikalskoe (1401), Yuzhno Sakhalinsk (1403). 
wave M2

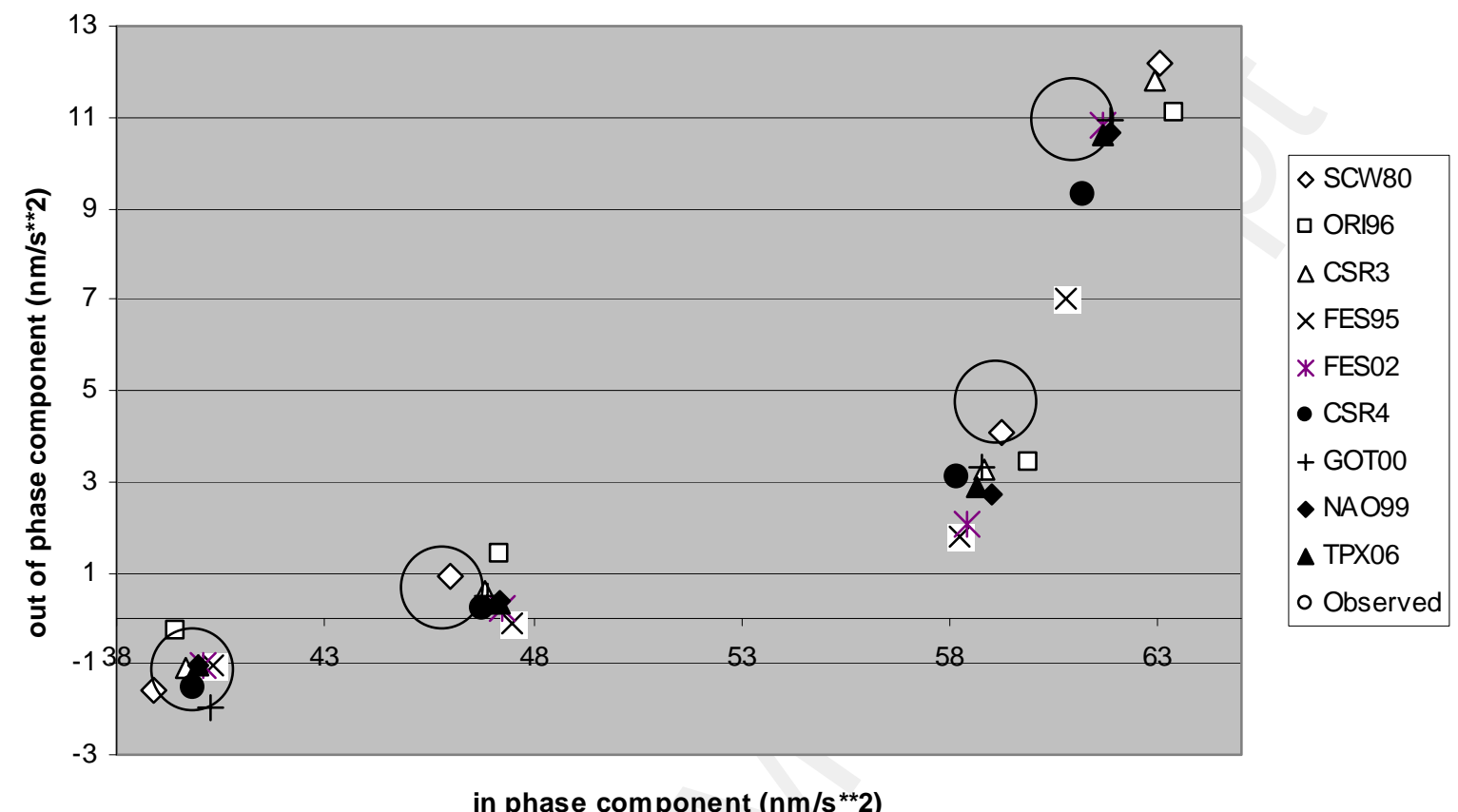

Figure 5: Comparison of the modelled $\mathbf{A}_{\mathbf{m}}$ and observed $\mathbf{A}$ tidal vectors for the wave M2. The horizontal scale has been adjusted by subtracting the astronomical amplitude $\mathrm{A}_{\text {th }}$ at each station.

From left to right: Novosibirsk (1289), Talaya (1301), Khabarovsk/Zabaikalskoe (1401), Yuzhno Sakhalinsk (1403). 